\title{
Teaching NeuroImages: Intracranial DICER1- associated spindle cell sarcoma in a child
}

Ali Rashidi, MD, Licia P. Luna, MD, PhD, Fausto Rodriguez, MD, and Aylin Tekes, MD

Neurology ${ }^{\circledR}$ 2020;95:e2176-e2177. doi:10.1212/WNL.0000000000010374

Figure $1 \mathrm{MRI}$ brain

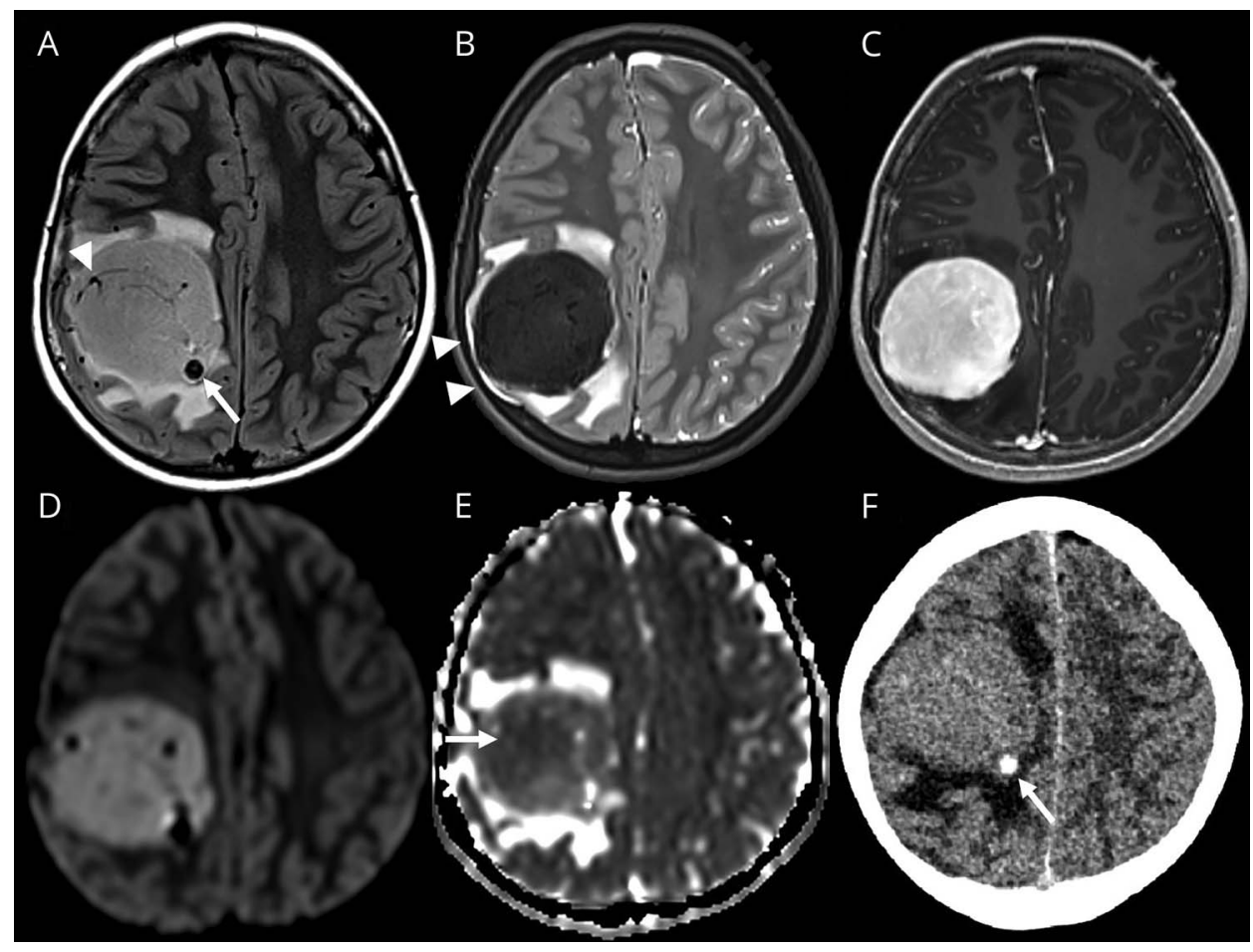

$\mathrm{D}$

-

Brain MRI reveals a right frontoparietal intraaxial mass, hyperintense on fluid-attenuated inversion recovery (A), hypointense on T2-weighted imaging (B), with marked enhancement on postcontrast T1-weighted imaging (C), areas of restricted diffusion on diffusion-weighted imaging (D) and apparent diffusion coefficient map (E, arrow), vascular structures ( $A$, arrowhead), and remodeling of the inner table ( $B$, arrowheads). A hyperdense focus on $C T$ (arrow in F) with a signal loss on MRI (arrow in A) was a large vein with mineralization on surgery. Differential considerations include embryonal tumors.

An 8-year-old boy presented with a 2-week history of worsening right-sided headache and leftsided jerking movements. Symptoms were associated with vomiting, photophobia, phonophobia, and diplopia but no loss of consciousness. cEEG demonstrated increased voltage on the right but no evidence of seizures. Brain MRI demonstrated a large right frontoparietal mass (figure 1). The pathologic findings were compatible with DICER1-associated pleomorphic spindle cell sarcoma (figure 2). Recently described, DICER1 mutation predisposes individuals to development of a subgroup of tumors termed "spindle cell sarcoma with rhabdomyosarcoma-like features, DICERI mutant" although it may present as "primary intracranial sarcoma, DICER1-mutant."1,2

\section{Correspondence}

Dr. Luna

Iluna6@jhmi.edu

\section{MORE ONLINE}

$\rightarrow$ Teaching slides

links.lww.com/WNL/

B175

From the Russell H. Morgan Department of Radiology and Radiological Science (A.R., L.P.L., A.T.) and Pathology Department (F.R.), Johns Hopkins University School of Medicine, Baltimore, MD.

Go to Neurology.org/N for full disclosures. Funding information and disclosures deemed relevant by the authors, if any, are provided at the end of the article. 


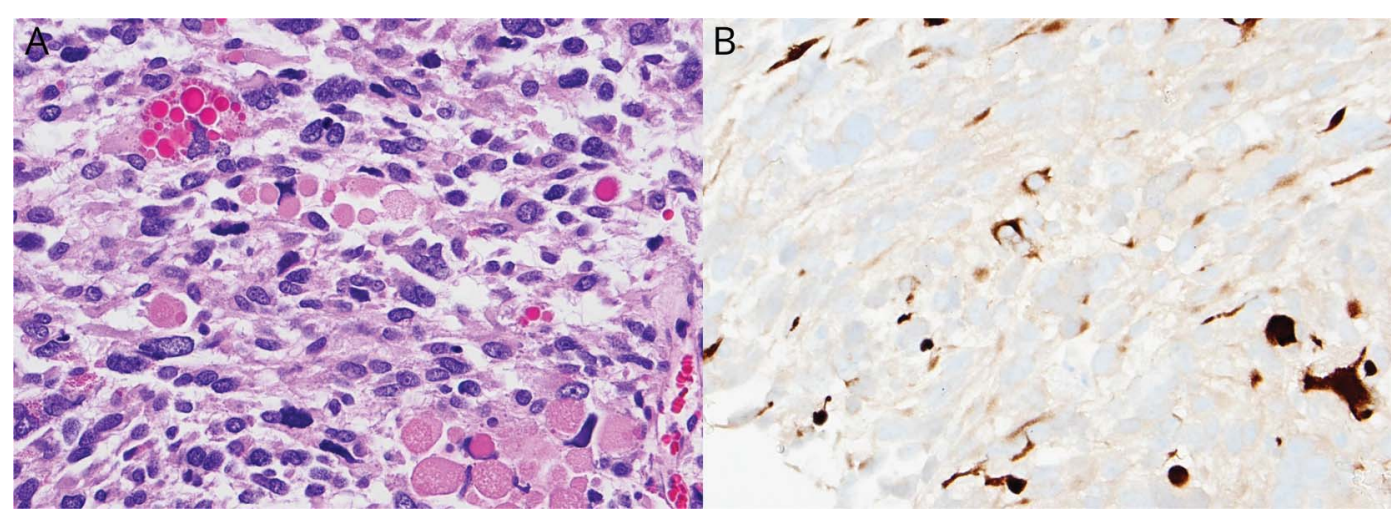

(A) Pleomorphic mesenchymal-appearing cells, some containing bright eosinophilic globules ( $\times 600)$. (B) Partial desmin immunoreactivity is typical ( $\times 600$ ).

\section{Study funding}

No targeted funding reported.

\section{Disclosure}

The authors report no disclosures relevant to the manuscript. Go to Neurology.org/N for full disclosures.

\section{Appendix Authors}

\begin{tabular}{lll}
\hline Name & Location & Contribution \\
\hline $\begin{array}{l}\text { Ali Rashidi, } \\
\text { MD }\end{array}$ & $\begin{array}{l}\text { Baltimore, } \\
\text { MD }\end{array}$ & Study concept and manuscript writing \\
\hline \begin{tabular}{lll} 
Licia P. Luna, & Baltimore, & $\begin{array}{l}\text { Study concept, major role in the acquisition } \\
\text { of data }\end{array}$ \\
\hline
\end{tabular} \\
\hline
\end{tabular}

\begin{tabular}{lll} 
Appendix & (continued) & \\
\hline Name & Location & Contribution \\
\hline $\begin{array}{l}\text { Fausto } \\
\text { Rodriguez, } \\
\text { MD }\end{array}$ & $\begin{array}{l}\text { Baltimore, } \\
\text { MD }\end{array}$ & Major role in the acquisition of data \\
\hline $\begin{array}{l}\text { Aylin Tekes, } \\
\text { MD }\end{array}$ & $\begin{array}{l}\text { Baltimore, } \\
\text { MD }\end{array}$ & $\begin{array}{l}\text { Critical revision of the manuscript for } \\
\text { important intellectual content, study } \\
\text { supervision }\end{array}$ \\
\hline
\end{tabular}

\section{References}

1. Lee JC, Villanueva-Meyer JE, Ferris SP, et al. Primary intracranial sarcomas with DICER1 mutation often contain prominent eosinophilic cytoplasmic globules and can occur in the setting of neurofibromatosis type 1. Acta Neuropathol 2019;137:521-525.

2. Sakaguchi M, Nakano Y, Honda-Kitahara M, et al. Two cases of primary supratentorial intracranial rhabdomyosarcoma with DICER1 mutation which may belong to a "spindle cell sarcoma with rhabdomyosarcoma-like feature, DICER1 mutant". Brain Tumor Pathol 2019;36:174-182. 


\section{Neurology}

Teaching NeuroImages: Intracranial DICERI-associated spindle cell sarcoma in a child Ali Rashidi, Licia P. Luna, Fausto Rodriguez, et al.

Neurology 2020;95;e2176-e2177 Published Online before print July 17, 2020

DOI 10.1212/WNL.0000000000010374

This information is current as of July 17, 2020

Updated Information \&

Services

References

Subspecialty Collections

Permissions \& Licensing

Reprints including high resolution figures, can be found at: http://n.neurology.org/content/95/15/e2176.full

This article cites 2 articles, 0 of which you can access for free at: http://n.neurology.org/content/95/15/e2176.full\#ref-list-1

This article, along with others on similar topics, appears in the following collection(s):

All Pediatric

http://n.neurology.org/cgi/collection/all_pediatric

CT

http://n.neurology.org/cgi/collection/ct

MRI

http://n.neurology.org/cgi/collection/mri

Primary brain tumor

http://n.neurology.org/cgi/collection/primary_brain_tumor

Information about reproducing this article in parts (figures,tables) or in its entirety can be found online at:

http://www.neurology.org/about/about_the_journal\#permissions

Information about ordering reprints can be found online:

http://n.neurology.org/subscribers/advertise

Neurology ${ }^{\circledR}$ is the official journal of the American Academy of Neurology. Published continuously since 1951, it is now a weekly with 48 issues per year. Copyright () 2020 American Academy of Neurology. All rights reserved. Print ISSN: 0028-3878. Online ISSN: 1526-632X.

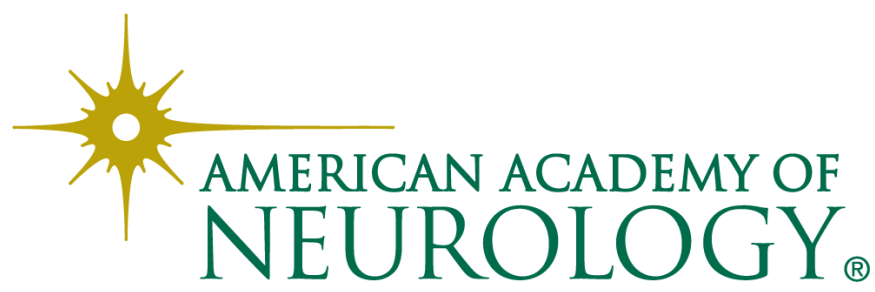

